\title{
Osmotic Dehydration Process for Preservation of Fruits and Vegetables
}

\author{
U. D. Chavan \\ Department of Food Science and Technology \\ Mahatma Phule Krishi Vidyapeeth, Rahuri 413722, India \\ R. Amarowicz \\ Institute of Animal Reproductions and Food Research of the Polish Academy of Sciences \\ Division of Food Science, Olsztyn, Poland
}

Received: March 6, 2012

Accepted: March 20, 2012 Published: May 1, 2012

doi:10.5539/jfr.v1n2p202

URL: http://dx.doi.org/10.5539/jfr.v1n2p202

\begin{abstract}
Osmotic dehydration has received greater attention in recent years as an effective method for preservation of fruits and vegetables. Being a simple process, it facilitates processing of fruits and vegetables such as banana, sapota, fig, guava, pineapple, apple mango, grapes, carrots, pumpkins, etc. with retention of initial fruit characteristics viz., colour, aroma, texture and nutritional composition. It is less energy intensive than air or vacuum drying process because it can be conducted at low or ambient temperature. It has potential advantages for the processing industry to maintain the food quality and to preserve the wholesomeness of the food. It involves dehydration of fruit slices in two stages, removal of water using as an osmotic agent and subsequent dehydration in a dryer where moisture content is further reduced to make the product shelf stable.
\end{abstract}

Keywords: Osmotic dehydration, Preservation, Fruits, Vegetables, Organoleptic quality

\section{Introduction}

Fruits and vegetables contribute a crucial source of nutrients in daily human diet. The world fruit production is estimated to be 434.7 million metric tones and vegetables 90.0 million metric tones. India is the second largest fruits and vegetable producer and its annual production is 44 million metric tones from an area of 3, 949, 000 ha during 2000-2002 (Srivastava \& Kumar, 2002). Fruits and vegetables losses in the developing countries are considerably high. In India, post harvest losses of fruits and vegetables are estimated as more than 25 percent.

Many processing techniques can be employed to preserve fruits and vegetables by drying and dehydration is one of the most important operations that are widely practiced because of considerable saving in packaging, storage etc.

Osmotic dehydration has received greater attention in recent years as an effective method for preservation of fruits and vegetables. Being a simple process, it facilitates processing of tropical fruits and vegetables such as banana, sapota, pineapple, mango, and leafy vegetables etc. with retention of initial fruit and vegetables characteristics viz., colour, aroma and nutritional compounds (Pokharkar \& Prasad, 1998). It is less energy intensive than air or vacuum drying processes because it can be conducted at low or ambient temperature. It has potential advantages for the processing industry to maintain the food quality and to preserve the wholesomeness of the food. It involves dehydration of fruit slices in two stages, removal of water using as an osmotic agent (osmotic concentration) and subsequent dehydration in a dryer where moisture content is further reduced to make the product shelf stable (Ponting, 1973).

Osmotic concentration is the process of water removal from fruits and vegetables, because the cell membranes are semi-permeable and allow water to pass through them more rapidly than sugar. During osmosis small quantity of fruit acid is removed along with water. It is a dynamic process, in which water and acid are removed at first and then move slowly, while sugar penetration is very slight at first but increases with the time. Therefore, 
the characteristics of the product can be varied by controlling temperature, sugar syrup concentration, concentration of osmosis solution, time of osmosis etc. to make osmotic concentration process faster.

\section{Application of Osmosis in Food Processing}

The osmotic dehydration process and influence of its process variables such as pretreatment, temperature of sugar solution and additives on the mass transfer in osmotic dehydration of various fruits was studied by Ponting et al. (1966) and reported that the apple slices reduced to 50 per cent of original weight by using $60-70{ }^{\circ} \mathrm{C}$ Brix sugar solution and superior quality. The study also indicated that there was no need of sulphur dioxide treatment to prevent loss of colour. The osmotic air-dried products were high in superior quality and reported that the osmosis process removed water from fruits and vegetables slices to the extent of $40-50$ per cent of the weight, but not enough for storage. Therefore, to remove water up to safe levels further drying is needed. Bongirwar and Sreenivasan (1977) indicated that the high temperature above $60{ }^{\circ} \mathrm{C}$ modifies the tissue characteristics favouring impregnation phenomena and thus solid gain. Rahman and Lamb (1991) reported the rate of sucrose diffusion is a function of solute concentration and temperature. The diffusion coefficient decreased with the increase in solid content during the osmosis and increased with the drying air temperature.

\section{Parameters Influencing the Osmotic Process}

Variables like maturity, variety, pretreatments, temperature, nature and concentration of osmotic agent, agitation, geometry of the material, fruit pieces to osmotic solution ratio, physico-chemical properties, additives, structure and pressure affecting the osmotic dehydration process. The effect of the process variables on mass transfer and product quality have been reviewed by Ponting et al. (1966), Torreggiani (1993), Raout Wack (1994), Pokharkar (1994), Lewicki and Lenart (1995), Sudheer and Dash (1999) and more recently by Rastogi et al. (2002).

\section{Raw Materials Characters for Osmotic Dehydration}

\subsection{Quality of raw material}

The variety and maturity of fruits and vegetables mainly control water loss and solid gain in the osmosis process. Among different fruits variability is mainly related to the tissue compactness, initial insoluble and soluble solids content, intercellular spaces and enzymatic activity of the fruit. The kinetic rate of solid gain did not depend significantly on solute concentration or process temperature. Among different varieties of mango Dashehari and Totapuri at ripe stage were found suitable for osmotic dehydration (Tiwari \& Jalali, 2004).

\subsection{Shape, size and thickness of the fruit pieces}

Water loss increases with increase in the surface area of fruit pieces. Panagiotou et al. (1998) observed that the size of fruit samples had a negative effect on water loss during osmotic treatment. Rahman (1992) observed that the distribution coefficient of water decreased with increasing temperature and surface area and it increased with the increase in syrup concentration and thickness of minimum geometric dimension. In general, a sample size of $3 \mathrm{~mm}$ to a maximum of $10 \mathrm{~mm}$ in rectangle, ring or cube shape was suggested for the use in osmotic dehydration process. The flow chart of general method of osmotic dehydration process is given Figure 1.

\section{Osmotic Process Parameters}

\subsection{Pretreatments}

Any pre treatment such as blanching or freezing prior to osmotic water removal was detrimental to the product quality. Dipping in 1 percent citric acid solution prior to drying or osmotic dehydration was used to prevent enzymatic browning of fruits. Immersion of product in alkaline or acid solutions of oleate esters prior to drying of fruits affected the prevention of discoloration (Hussain et al., 2004; Sunkja \& Ragharan, 2004). Torreggiani, (1993) reported that pretreatment with chemicals $\left(\mathrm{SO}_{2}\right)$, or blanching prior to drying of fruits and vegetables effected the prevention of discolouration. Dipping the papaya and mango slices in 0.4 percent ascorbic acid solution or 0.4 per cent ascorbic acid +0.1 percent KMS solution for 30 min prior to osmosis process effected to obtain a high acceptable product.

\subsection{Immersion time}

Keeping the concentration of the solution constant, the increase of the immersion time resulted in the increase of water loss, but the rate of increase was decreased. Studies on the optimization of duration of osmosis process indicated that mass exchange took place at the maximum rate within the first two hrs of the osmotic treatment. Tiwari and Jalali (2004) reported that during osmotic dehydration of mango and pineapple increase in osmotic duration resulted in increase in weight loss, but the rate of which occurs decreases. Gaspartero et al. (2003) and Mauro et al. (2004) reported that when banana and apple slices dipped in 70 and $50{ }^{\circ}$ Brix respectively, osmotic solution temperature of $50{ }^{\circ} \mathrm{C}$ for $3 \mathrm{hrs}$ immersion time gave optimum water loss and sugar gain. Osmotic 
dehydration process followed by air-drying at $60^{\circ} \mathrm{C}$ temperature with the air velocity of $2 \mathrm{~m} / \mathrm{s}$ up to a constant weight.

\subsection{Temperature of the osmotic solution}

The temperature of osmotic solution markedly affected the rate of osmosis. Although the rate increased with temperature, it was limited up to $60{ }^{\circ} \mathrm{C}$ as higher temperature destroyed the cell membranes. Pokharkar and Prasad (1998) developed kinetic model for osmotic dehydration of banana slices and reported that the temperature of the osmotic solution affected the parameters like water and sugar gain of osmosis process.

\subsection{Osmotic agents}

Several studies were conducted to find out the effect of different osmotic agents on the osmotic dehydration process. The most commonly used osmotic agents were sucrose, glucose for fruits and $\mathrm{NaCl}$ for vegetables. Other osmotic agents include Calcium chloride, monohydroxy ethanol and polyhydroxy compounds such as lactose, malt dextrin, corn syrup and mixtures of these items. The effects of various osmotic agents are presented in Table 1.

\subsection{Concentration of osmotic solution}

Rahman and Lamb (1990) pointed out that water loss and sugar gain increased linearly with the increase of sugar concentration and temperature. The rate of sugar diffusion was a function of sugar concentration and temperature. Concentration of solution is a key factor in the osmotic dehydration process and many research workers have studied the effect of osmotic solution concentration on mass transfer of osmotic dehydration process. In general, syrup strength in the range of 60 to $70{ }^{\circ} \mathrm{Brix}$ has been found to be optimum (Chaudhary et al, 1993). It was also reported that higher concentration, faster is the rate of osmosis. Torreggiani (1993) suggested that, it was usually not worthwhile using higher concentration for osmosis process for more than 50 per cent of weight reduction because of decrease in osmotic rate with time.

\subsection{Agitation / Circulation}

When fruits are agitated in syrup, the rate of osmosis will be faster due to reduced mass transfer resistance at the surface by avoiding localized dilution process. But, it may cause damage to sample. Panagiotou et al, (1998) and Tiwari (2005) observed that the speed of agitation had a positive effect on water loss during osmotic treatment.

\subsection{Fruit pieces to osmotic solution ratio}

With an increase in solution to sample ratio, the rate of osmosis increases up to a certain extent. However, it is essential to use an optimum ratio since large ratios offer practical difficulties in handling the syrup fruit mixture for processing. A ratio of 1:2 or 1:3 is optimum for practical purposes (Tiwari, 2005).

\section{Kinetic of Osmotic Dehydration}

The kinetic of osmotic dehydration is determined by estimating the rate of water removal and solid gain. Generally higher rates of water removal take place within first hour of osmosis due the large driving force between the dilute fruit sap and osmotic solution (Sharma et al., 2004).

\section{Mass transfer phenomena during osmotic dehydration}

There are three major types of counter current mass transfer in osmotic concentration process (Karthiayani, 2004; Tiwari, 2005) (Figure 2).

1. Important water out flow from product to solution.

2. A solute transfer, from the solution to the product; it makes thus possible to introduce the desired amount of an active principle, a preservative agent, any solute or nutritional interest, or a sensory quality improvement of the product.

3. Leaching out of products own solutes (sugar, organic acids, minerals, vitamins etc.), which is quantitatively negligible when compares with the first two types of transfer, but essential with regard to the composition of final product.

The schematic diagram of mass transfer during osmosis process is given in Figure 2.

\section{Drying Behaviour of Osmotically Concentrated Fruits}

The high temperature short time drying process was possible for osmo-dried products as those having low moisture content. Generally osmotic concentration would not give low moisture content to be stored for long time. Osmo-dried products should be processed further (air drying, vacuum drying etc.) to obtain shelf-stable 
products (Pointing, 1973). The osmo dried papaya and mango slices were dried in a cabinet dryer at $60{ }^{\circ} \mathrm{C}$ for 6 hrs to obtain 16 per cent moisture content (Gurumeenakshi et al., 2005).

\section{Packaging of Osmotically Dehydrated Products}

In order to prevent absorption of moisture from atmosphere and to prevent spoilage due to contamination, good quality, food grade and airtight containers can be used to store osmotically dried foods. Aluminum foil, laminated polypropylene pouches are suggested as ideal packing materials (Sagar \& Khurdiya, 1999). Ahemed and Choudhary (1995) used high-density polyethylene pouches for osmo-dried papaya. Dried products were kept at room temperature for six months and it was accepted with little changes.

\section{Storage of Osmotically Dehydrated Products}

The storage stability of osmotically dehydrated products varies from six months to one year. The papaya product obtained from osmotic dehydration process remains stable up to six months of storage at room temperature (Ahemed \& Choudhary, 1995). Bongirwar and Sreenivasan (1977) reported that the osmotically dehydrated banana products can be preserved up to one year or more depending upon the storage conditions and packaging materials used. Storage studies on osmo-dehydrated mango slices showed that the keeping relative humidity between 64.8 to 75.5 per cent would be conducive for the retention of colour, flavour, texture and taste.

\section{Microbial Studies of Osmo-dehydrated Products}

Ramarjuna and Jayaraman (1980) studied the microbial quality of intermediate moisture banana stored at $0{ }^{\circ} \mathrm{C}$ and $37^{\circ} \mathrm{C}$ and showed that at $0{ }^{\circ} \mathrm{C}$ the total plate count was 250 to 300 colonies/g but at room temperature and 37 ${ }^{0} \mathrm{C}$, it was negligible and product was microbiologically safe for direct consumption. Khandekar et al, (2005) carried out research on standard plate count of fig toffee after six months of preservation. The toffees, which were treated with sodium benzoate, reported lower microbial count $\left(11 \times 10^{3} / \mathrm{g}\right)$ compared to untreated toffee $\left(23 \times 10^{3} / \mathrm{g}\right)$.

\section{Advantages of Osmotic Dehydration}

There are number of advantages of the osmotic dehydration process.

1. It minimizes the effect of temperature on food quality and preserves the wholeness of the food, as no high temperature/phase change is required in the process.

2. Mild heat treatment favours colour and flavour retention resulting in the product having superior organoleptic characteristics. It is more when sugar syrup is used as osmotic agent.

3. IT increases resistance to heat treatment

4. The process is quite simple, economical (energy requirement is 2-3 times less as compared to the conventional drying.

5. It prevents the enzymatic browning and inhibits activities of polyphenol oxidases.

6. It improves the texture and rehydration properties

7. The blanching process may be eliminated by this process, which reduces cost of processing

8. Acid removal and sugar uptake by fruits modifies the composition and improves the taste and acceptability which is called candying effect

9. The process could prove to be good for production of the ready to eat foods such as raisins etc.

10. The process reduces volume of the products thereby saving in the cost of processing, storage and transport

11. Constant immersion of product in osmotic agents avoids the $\mathrm{O}_{2}$ exposure, the product retains better colour

12. It protects against the structural collapse of the product during subsequent drying. It helps to retain the shape of the dehydrated products

\section{Conclusions}

Osmotic dehydration process being a simple process, it facilitates processing of tropical fruits and vegetables such as banana, sapota, pineapple, mango, guava, carrot, pumpkin, papaya etc with retention of initial fruit characteristics viz., colour, aroma and nutritional compounds. In preservation of fruits and vegetables osmotic dehydration process add value to the finished product, which is wholesome, nutritious and available round the year. 


\section{References}

Ahemed, J., \& Choudhary, D. R. (1995). Osmotic dehydration of papaya. Indian Food Pack, 49, 5-11.

Biswal, R. N., \& Maguer, Le. (1989). Mass transfers in plant material in contact with aqueous solution of ethanol and sodium chloride equilibrium data. J. Food Process Eng., 11, 159-176.

Bolin, H. R., Huxsoll, C. C., \& Jackson, R. (1983). Effect of osmotic agents and concentration on fruit quality. J. Food Sci. Technol, 48, 202-205. http://dx.doi.org/10.1111/j.1745-4530.1989.tb00027.x

Bongirwar, D. R., \& Sreenivasan, A. (1977). Osmotic dehydration of banana. J. Food Sci. Technol, 14 (3), 104-112.

Chaudhari, A. P., Kumbhar, B. K., Singh, B. N. N., \& Narain, M. (1993). Osmotic dehydration of fruits and vegetables. Indian Food Industry, 12, 20-27.

Farkas, D. F., \& Lazor, M. E. (1969). Osmotic dehydration of apple pieces. Effect of temperature and syrup concentration. J. Food Sci. Technol, 23, 668-690.

Flink, J. M. (1975). Processing conditions for improved flavour quality of freeze-dried foods. J. Agric. Food Chem, 23 (6), 1019-1026. http://dx.doi.org/10.1021/jf60202a018

Gaspartero, O. C. P., Silva, P. D. L., \& Gertrudes, E. (2003). Study of conservation of banana by osmotic dehydration and drying in a conventional dryer. J. Chemi. Eng, 3, 25-29.

Gurumeenakshi, G., Manimegalai, G., Maragatham, S., \& Jeberaj, S. (2005). Ascorbic acid and KMS as new food additives for osmo dried foods. Beverage Food World, 32 (7), 50-51.

Hawkes, J., \& Flink, J. M. (1978). Osmotic concentration of fruit slices prior to freeze dehydration. J. Food Proc. And Preservation, 2, 265-284. http://dx.doi.org/10.1111/j.1745-4549.1978.tb00562.x

Hussian, I., Iqbal, M., \& Arub, N. (2004). Effect of sucrose and glucose mixture on the quality characteristics of osmotically dehydrated banana slices. Pakistan J. Nutrition, 46, 83-92.

Karthiayani, A. (2004). Osmotic dehydration of fruits and vegetables with special reference to vacuum treatment. Food and Pack, 39, 82-84.

Khandekar, S. V., Chavan, U. D., \& Chavan, J. K. (2005). Preservation of pulp and preparation of toffee from fig fruit. Beverage and Food World, 32, 55-56.

Lenart, A., \& Flink, J. M. (1984). Osmotic concentration of potato. Criteria for the end point of the osmotic process. J. Food Sci. Technol, 19, 45-63.

Lewicki, P. P., \& Lenart, A. (1995). Osmotic dehydration of fruits and vegetables. In Handbook of Industrial Drying, Second edn. By Mujumdar, A. S., Marcel Dekker Inc. New York. pp. 691-713.

Mauro, A. M., Mounnrat, S. M., \& Rodrogues, A. E. (2004). Vacuum drying of osmotic dehydrated apple slices. Drying, 2004, Proceedings of the $14^{\text {th }}$ International drying Symposium, Brazil.

Panagiotou, N. M., Karathanos, V. T., \& Maroulis, Z. B. (1998). Mass transfer modeling of the osmotic dehydration of some fruits. Int. J. Food Sci. Technol, 33, 267-284. http://dx.doi.org/10.1046/j.1365-2621.1998.00167.x

Pointing, J. D. (1973). Osmotic dehydration of fruits, recent modifications and applications. J. Process Bio Technology, 12(8), 8-20.

Pointing, J. D., Watterss, G. G., Forrey, R. R., Stangly, W. L., \& Jackson, R. (1966). Osmotic dehydration of fruits. J. Food Sci. Technol, 20 (10), 125-128.

Pokharkar, S. M. (1994). Studies on osmotic concentration and air-drying of pineapple slices. Ph.D. Thesis, Department of Agril. Engineering, Indian Institute of Technology, Kharagpur. Pp. 22-68.

Pokharkar, S. M., \& Prasad, S. (1998). Mass trasfer during osmotic dehydration of banana slices. J. Food Sci. Technol, 35 (4), 336-338.

Rahman, M. S. (1992). Osmotic dehydration kinetics of foods. Indian Food Industry, 11 (5), 20-24. http://dx.doi.org/10.1111/j.1745-4530.1991.tb00088.x

Rahman, M. S., \& Lamb, J. (1991). Air-drying behaviour of fresh and osmotically dehydrated pineapples. J. Food Process Engi, 14, 163-171.

Ramarjuna, M. N., \& Jayaraman, K. S. (1980). Studies on the preparation and storage stability of intermediate banana. J. Food Sci. Technol, 17, 183.

Raout Wack, A. L. (1994). Recent advances in the osmotic dehydration of fruits. J. Food Sci. Technol, 5, 255-260. http://dx.doi.org/10.1016/0924-2244(94)90018-3 
Rastogi, N. K., Ragavarao, K. S. M. S., Niranjan, K., \& Knorr, D. (2002). Recent developments in osmotic dehydration: Methods and enhance mass transfer. Trends in Food Sci. Technol, 13, 48-59. http://dx.doi.org/10.1016/S0924-2244(02)00032-8

Sagar, V. S., \& Khurdiya, D. S. (1999). Studies on dehydration of Dashehari mango slices. Indian Food Pack, 53(1), 5-9.

Sharma, K. D., Kunen, R., \& Kaushal, B. B. L. (2004). Mass transfers Characteristics of yield and quality of five varieties of osmotically dehydrated apricot. J. Food Sci. Technol, 41, 264-275.

Srivastava, R. P., \& Sanjeev Kumar. (2002). Fruit and Vegetable Preservation, Principles and Practices. Third edn. Army printing press Lucknow. India. Pp. 11-20.

Sudheer, K. P., \& Dash, S. K. (1999). Osmo solar dehydation of ruits and vegetables. An overview. Indian Food Pack, 53 (3), 28-39.

Sunkja, P. S., \& Ragharan, G. S. V. (2004). Assessment of pre treatment methods and osmotic dehydration of Cranberries. J. Canadian Bio systems, 46, 52-56.

Tiwari, R. B. (2005). Application of osmo air dehydration for processing of tropical fruits in rural areas. Indian Food Industry, 24(6), 62-69.

Tiwari, R. B., \& Jalali, S. (2004). Studies on osmtic dehydration of different varieties of mango. In proceeding of First Indian Horticulture congress-2004, New Delhi.

Torreggiani, D. (1993). Osmotic dehydration in fruit and vegetable processing. Food Res. Intl, 26, 59-68. http://dx.doi.org/10.1016/0963-9969(93)90106-S

Table 1. Different osmotic agents and their effects in osmotic dehydration process

\begin{tabular}{|c|c|c|}
\hline Osmotic agent & Remark & Reference \\
\hline Calcium Chloride & $\begin{array}{l}\text { Increases the firmness of apple slices and preserves the } \\
\text { texture during storage. Prevents browning because of } \\
\text { synergistic effect with ascorbic acid or sulphur dioxide. } \\
\text { Imparts better taste to the product if used above } 0.5 \text { per cent } \\
\text { level. }\end{array}$ & Pointing, 1973 \\
\hline Ethanol & $\begin{array}{l}\text { Decreases viscosity and freezing and freezing point of the } \\
\text { osmotic solution in cooling and freezing processes. }\end{array}$ & $\begin{array}{l}\text { Biswal and } \\
\text { Maguer, } 1989\end{array}$ \\
\hline Fructose & $\begin{array}{l}\text { Increases the dry matter content by } 50 \text { per cent as compared } \\
\text { to sucrose due to higher penetration rate. Water activity of } \\
\text { the final product is also lower. However sucrose is } \\
\text { preferred over fructose. }\end{array}$ & Bolin et al., 1983 \\
\hline Invert sugar & $\begin{array}{l}\text { Theoretically more effective than same concentration of } \\
\text { sucrose because when completely inverted, it has twice as } \\
\text { many molecules per unit volume. Practically little } \\
\text { difference in the rate of osmotic dehydration of fruit by } \\
\text { sucrose or invert syrups of the same concentration and } \\
\text { temperature. }\end{array}$ & Pointing et al., 1966 \\
\hline Lactose & $\begin{array}{l}\text { It has much lower level of sweetness than sucrose. Low } \\
\text { solubility in aqueous solution. }\end{array}$ & $\begin{array}{l}\text { Hawkes and Flink, } \\
1978\end{array}$ \\
\hline Malto Dextrin & $\begin{array}{l}\text { It can be used as an osmosis solute at higher total solids } \\
\text { concentration, or in mixed systems. Less effective than } \\
\text { sucrose at the same concentration. }\end{array}$ & $\begin{array}{l}\text { Hawkes and Flink, } \\
1978\end{array}$ \\
\hline Sodium Chloride & $\begin{array}{l}\mathrm{NaCl} \text { : Mostly used for vegetables as it retards oxidative and } \\
\text { non-enzymatic browning. Increases the driving force for the } \\
\text { drying owing to the lowering capacity of the salt. } \\
\text { Sometimes blanching effect on coloured products can be } \\
\text { prevented using mixture of salt and sugar. Organoleptic } \\
\text { should be } 10-12 \text { per cent. Hinders shrinkage at the surface } \\
\text { layers. }\end{array}$ & $\begin{array}{l}\text { Hawkes and Flink, } \\
1978, \\
\text { Lenart and Flink, } \\
1984\end{array}$ \\
\hline Sucrose / Sugar & $\begin{array}{l}\text { Dry sugar is unsuitable because of oxidative browning } \\
\text { during osmosis. Difficulty in disposing sugar syrup. Sugar } \\
\text { solution is best as it reduces browning by preventing the } \\
\text { entry of oxygen. Sweetness hinders its use in vegetable } \\
\text { processing. }\end{array}$ & $\begin{array}{l}\text { Pointing et al, } 1966 \text {, } \\
\text { Farkas and Lazer, } \\
\text { 1969, Flink, } 1975\end{array}$ \\
\hline Starch / Corn syrup & $\begin{array}{l}\text { Favours similar final water content with minimal solid gain } \\
\text { as that obtained with sucrose. }\end{array}$ & Flink, 1975 \\
\hline
\end{tabular}


Selection of raw material

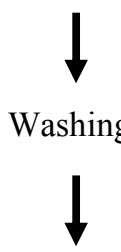

Preparation of fruits

(Slices/Pieces or as required)<smiles>[AlH2]</smiles>

Pretreatment,

Sulfuring, Vacuum impregnation,

Blanching, Antioxidant etc.<smiles>[AlH2]</smiles>

Osmotic treatment

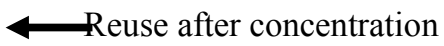

* Osmotic solution

* Immersion time

* Temperature

* Fruit to syrup ratio

* Agitation

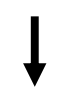

Draining

Sugar syrup

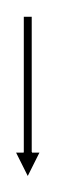

Dehydration of fruits slices

* Cabinet drying

* Solar drying

* Vacuum drying

* Freeze-drying

$\downarrow$

Packaging, Labeling and Storage

Figure 1. Flow chart of general method of osmotic dehydration process 


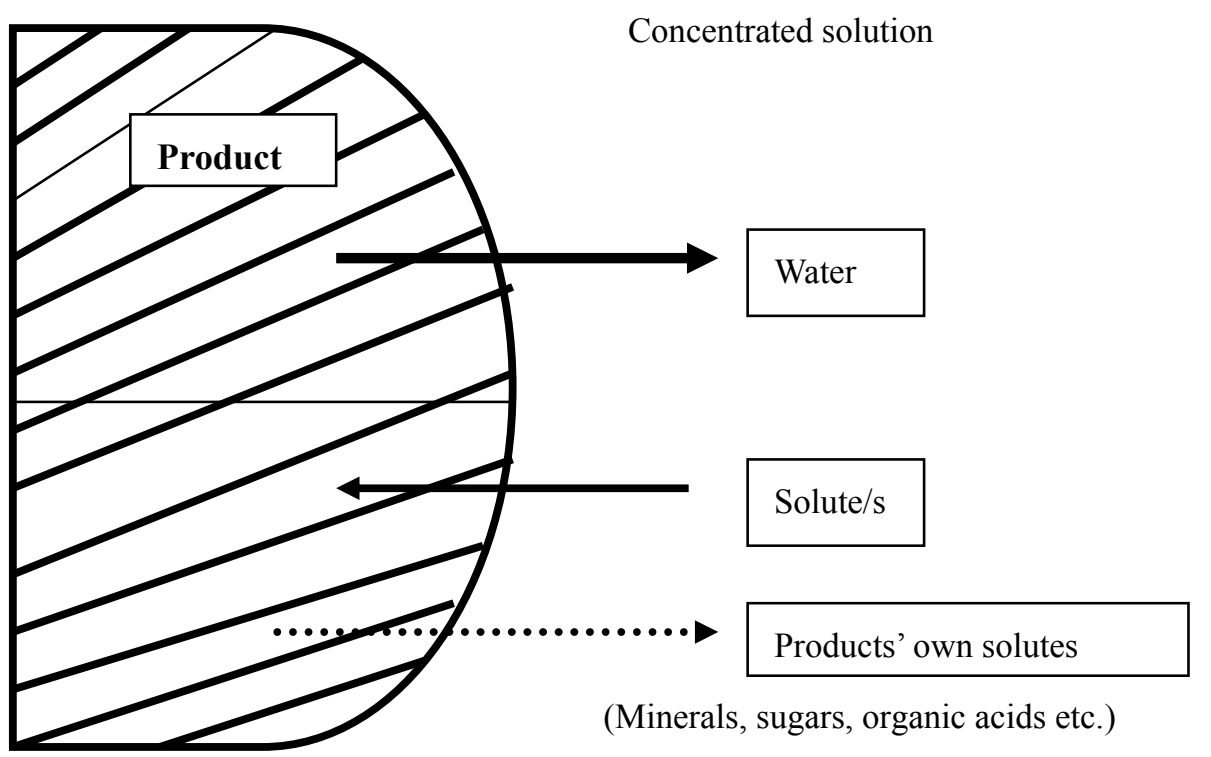

Figure 2. The schematic diagram of mass transfer during osmosis process (Raoult-Wack, 1994) 